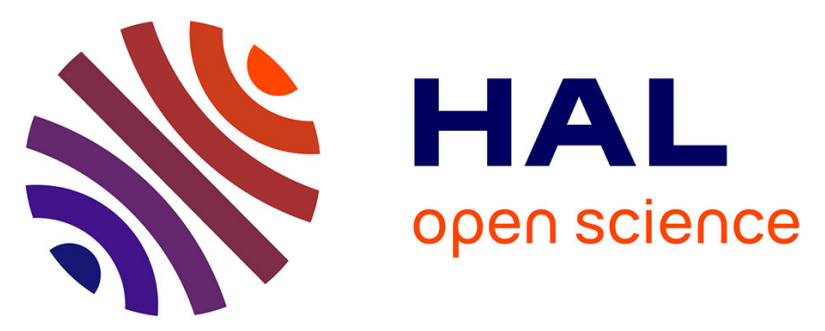

\title{
Street trade, neoliberalisation and the control of space: Nairobi's Central Business District in the era of entrepreneurial urbanism
}

Marianne Morange

\section{- To cite this version: \\ Marianne Morange. Street trade, neoliberalisation and the control of space: Nairobi's Central Business District in the era of entrepreneurial urbanism. Journal of Eastern African Studies, 2015, 9 (2), pp.247 - 269. 10.1080/17531055.2015.1018407 . hal-01468094}

\author{
HAL Id: hal-01468094 \\ https://hal.science/hal-01468094
}

Submitted on 15 Feb 2017

HAL is a multi-disciplinary open access archive for the deposit and dissemination of scientific research documents, whether they are published or not. The documents may come from teaching and research institutions in France or abroad, or from public or private research centers.
L'archive ouverte pluridisciplinaire HAL, est destinée au dépôt et à la diffusion de documents scientifiques de niveau recherche, publiés ou non, émanant des établissements d'enseignement et de recherche français ou étrangers, des laboratoires publics ou privés.

\section{(ㅇ)(1) $\$$}

Distributed under a Creative Commons Attribution - NonCommercial - NoDerivatives 44.0 


\title{
Street trade, neoliberalisation and the control of space: Nairobi's CBD in the era of entrepreneurial urbanism
}

\author{
Marianne Morange, Associate Professor - Maître de conférences habilitée à diriger des \\ recherches
}

Department of Geography, University Paris Diderot-PRES Sorbonne-Paris-Cité, CESSMA UMR 245, Junior fellow of the Institut Universitaire de France

marianne.morange@univ-paris-diderot.fr

\begin{abstract}
Studies focusing on street trade in Sub-Saharan Africa place great importance on the continuity with the colonial period and on the neocolonial characteristics of public action. This frame of reference, however pertinent it might be, does not account for all of the dynamics at work. I argue that it can benefit from an additional reading of what I characterize as the neoliberal dynamics also at work in these processes, drawing from governmentality studies and from the theories of "the urbanisation of neoliberalism". The paper discusses this hypothesis by examining the evolution of spatial politics on the streets of Nairobi's Central Business District in the 2000s, focusing on a specific episode: the displacement of the street traders to an enclosed market located on the outskirts of the CBD. The first section considers the policies of street trade in Nairobi since the colonial period and the changes in their meaning under entrepreneurial rule, questioning the hypothesis of the colonial continuity. I then turn to an analysis of the neoliberal features of current street trade policies. I detail the emergence of the private sector as a major actor in the governance of street trade and its instrumental role in the crafting of a consultative procedure that has helped to reframe the traders' relationship to the state around the ideal of the responsible entrepreneurial citizen and contributed to enrolment as active participants in their own relocation.
\end{abstract}

Keywords: Nairobi; street trade; entrepreneurial urbanism; neoliberal governmentality; PPP; participation

Street trading is a distinctive feature of African cities. It gained international recognition as a vital component of domestic reproduction, political stability, and the urban economy, in the 1970s, following years of obliviousness or denigration by national governments and international agencies. Kenya was pivotal in this recognition: as street trade was booming under the combined pressure of urban growth, political instability in rural areas and increasing unemployment, an ILO mission to Kenya (1972) popularised issues of informality, a notion coined by Hart ${ }^{1}$ in his seminal work on Ghana, within developmental and governmental circles. It led to a better political recognition of jua kali (burning sun) artisans in Kenya ${ }^{2}$. However, their presence in public space remained problematic in terms of city planning, and both the State and the Nairobi City Council (NCC) continued to enforce relocations and evictions.

In the late 1990s, entrepreneurial concerns hit African cities and street trade grew to become a major problem at the city level all over the continent (in Dar as Salaam ${ }^{3}$, Accra ${ }^{4}$, Durban $^{5}$, Lome or Abidjan ${ }^{6}$ ). The Kenyan state embraced entrepreneurialism, endeavouring to make Nairobi, the largest city of Kenya with 3,134,000 inhabitants ${ }^{7}$, "one of the most attractive 
cities in the world" (D. Wathika, former Mayor) ${ }^{8}$. A private agency, the Nairobi Central Business District Association (NCBDA), was formed by prominent corporate firms in order to regenerate and regain control of the $\mathrm{CBD}$ through beautification programmes and increased security, and by discarding undesirable behaviours and activities. As a result, in 2007, all the street traders of the CBD were displaced to the Muthurwa market, a formal trading area located on the outskirts of the city centre.

Studies looking at the regulation of street trade thus emphasize continuity with the colonial period and the neocolonial characteristics of contemporary public action ${ }^{9}$. This frame of reference, however pertinent it might be, does not account for all of the dynamics at work today. It could benefit from an additional reading of the neoliberal dynamics that may also be at work in these processes, interwoven with postcolonial dynamics.

Urban studies inspired by neo-Marxist political economy and neo-Foucauldian governmentality studies give two distinct interpretations of neoliberalism, i.e. the spread of competitive and market principles to all spheres of public and private life:

The former highlight the fact that the spread of these values among local governments encourages the adherence to what D. Harvey called urban entrepreneurship: the quest for competitiveness through urban renewal policies, in particular in the inner city, intended to achieve a favorable position on the "market" of global cities; reforms to local governance (dismantlement of public agencies for the provision of urban services, propagation of New Public Management in local government, the proliferation of public-private partnerships...); and the abandonment of spatial planning in favor of strategic planning, i.e. "city visions", the new shibboleth of competitive regionalism. Since these new practices were partially forged in the arenas of urban governance, Brenner and Theodore speak of the "urbanization of neoliberalism"10.

Governmentality studies that draw from M. Foucault's conceptualization of power refer to "market-oriented neoliberal governmentalities"11. By this, they mean the emergence of a society of control based on the extension of market-principle to everyday life. This is said to be achieved through the discursive reframing of government problems, the construction of new technologies of control, and the constitution of new forms of authorities. Neoliberalisation is seen not only as an ideology that leads to the reshaping of governance structures and political policies; it is a rationality that is spreading among 'ordinary' city-dwellers, "extend[ing] beyond formalized frames of governance" (Nadesan p. 15) ${ }^{12}$ and domains of state activities. With the crafting of self-governed subjects (individuals "engag[ing] actively in 'self-governement" "13) who embrace competition and a moral sense of individual responsibility, new arts of government are spreading that rely on the exercise of individual freedom, marking a partial break with disciplinary processes and with the exercise of state sovereignty through the law.

My approach stands at the intersection of these two fields. It seeks to question their respective contributions to the understanding of the quarantining of the street traders of Muthurwa market, a perfect lockdown that the authorities had vainly sought to achieve by force since colonization. My hypothesis is that the fact that this was possible in 2007 is notably attributable to the appearance of entrepreneurial practices in urban policies. It led to a partial reformulation of the "problem" of street trading around the idea of urban competitiveness. Since 
Independence, the driver for spatial control in the CBD has indeed changed from a concern for protecting the core of the national capital and the image of the emerging Nation state, to a compliance to global economic competitiveness. As a result, image issues tend to be framed primarily in terms of global economic attractiveness. This shift in priorities coincides with a more direct involvement of the private sector in urban planning matters. It led to changes in local governance that played a driving role in the introduction of a new consultative process which was able to influence the behavior of street traders by promoting their entrepreneurial identity and their desire for respectability. While theories of the urbanization of neoliberalism explain certain changes in the governance of street trading in central Nairobi, they do little to help us interpret the power process underlying this eviction, because they emphasize the repressive image of the entrepreneurial state. Governmentality studies, on the other hand, offer avenues for using this episode as a basis for discussion of the possible emergence of liberal crafts of governing based on an entrepreneurial rationale in a newly democratizing Nairobi.

The first section of the paper questions the colonial continuity hypothesis through an analysis of the policies of street trade in relation to urban planning and of their changing meaning in the globalising entrepreneurial context (the reframing of the 'problem' of street trade under entrepreneurial urbanism). The second and the third sections turn to an analysis of their neoliberal characteristics. I start by detailing the emergence of a PPP structure that strives to enhance its spatial control over the city core, deepening the inherited centre-periphery dichotomy. In the last section, I analyse the concrete power practices attached to the consultative process that led to the relocation to Muthurwa. The opening up of the political space in Kenya has indeed led to the crafting of a ground-breaking consultative process: Street traders in Nairobi were invited to participate in their relocation through a seemingly inclusive consultative process. It helped to defuse their protest by reframing their relationship to the state around the ideal of the responsible entrepreneurial citizen.

In this paper, street trading is not scrutinised per se as an economic activity ${ }^{14}$. It is used as an entry-point into the empirical assessment of neoliberalisation at the city level. The paper relies on the reading of press material, promotional pamphlets, research material and reports, Website communication documents, and 15 interviews with key actors of the NCBDA, KENASVIT (the Kenya National Alliance of Street Vendors and Informal Traders) and NISCOF (the associational member of KENASVIT that was pivotal in the relocation to Muthurwa). I interviewed traders who operated in Muthurwa only. The fieldwork was conducted in June 2008, three months after the traders had been relocated to Muthurwa. I came back to Nairobi in June 2010 in order to assess the changes on the ground. Complementarily, I read the archives of the Nairobi City Commission and of the Nairobi County Council in order to discuss the colonial (dis)continuity hypothesis ${ }^{15}$.

\section{Street trade, urban planning and conflicting images of the city}

\section{The (un)changing policies of street trade since the colonial era?}

Following the return of the vendors to the streets of the CBD after they had been chased for the umpteenth time, the Mayor of Nairobi made a blunt statement on a highly symbolic 
occasion, using a term (hawker) that is often heard in Nairobi despite its derogatory connotation:

"We know the issue of hawkers invading the central Business District is a sensitive one. We know
they need to earn a living. But we also know that the Central Business District is not designed for
hawking" (D. Wathika, message on the $42^{\text {nd }}$ anniversary independence, www.nairobicity.go.ke,
May 2008, accessed February 2009) $)^{16}$

Conflicting uses and images of the city core have always fuelled the planning debate in Nairobi, and street trading has always been envisioned by public authorities as an untidy activity that needed to be regulated ${ }^{17}$. Street traders do not have problems; they are the problem, mainly because whatever the estimation, they are numerous and there is a sense that their activity is running out of control, thus the image of invasion used by $\mathrm{D}$. Wathika. There are from 50,000 to 100,000 street vendors in the metropolitan area ${ }^{18}, 30,000$ in Central Nairobi ${ }^{19}$, and $6,000^{20}$ to 14,000 in the $\mathrm{CBD}^{21}$. Street traders are gathered and thus highly visible in the city core, a $2 \mathrm{~km}^{2}$ square within which public authorities have constantly strived to limit their capacity to operate.

Street trade, once a central government responsibility (of the African Affairs Officer and Commissioner), became a municipal affair in the late 1930s. Municipal bylaws on street trade were repeatedly amended from the 1930s onward, with an acceleration in the early 1960s due to the end of the Emergency state and the massive arrival of migrants that led to a change in scale of street trade. The 1963 bylaw $\mathrm{N}^{\circ} 748$ was made by order of the City Council in November 1963. It was approved by the central State on 2 December 1963 and it was published in the Kenya Gazette on 17 December, i.e. five days after Independence. Under these bylaws the City inspectorates (askaris) developed a tradition of harassing "illegal" traders, demolishing their kiosks and enforcing expensive penalties on them.

This repressive approach was rooted in a praise of hygienism and modernity that can be traced back to the 1948 Nairobi Master Plan ${ }^{22}$ (Figure 1a). The plan drew from the principles of functionalism that prevailed in European and South African planning ${ }^{23}$. It paved the way for a strict control over street trading especially within the civic centre (the administrative core). Despite difficulties in implementing it, this remained the reference document in urban planning until 1973. After independence, street trading remained a planning challenge with regards to public space, traffic congestion, and refuse collection, while its borderline-illegal quality continued to feed the fear of crime ${ }^{24}$.

In the early 1970s, the Kenyan state developed a more tolerant approach toward Small and Medium Enterprises (SMEs). The national government's Economic Planning Strategy ${ }^{25}$ and the 1973 Metropolitan Growth Strategy recognised street trading as a major source of livelihood and an outcome of unemployment. Informal activities represented $74.2 \%$ of employment nationally in the mid-2000s ${ }^{26}$ and SMEs grew from 4.2 million jobs in 2001 to 5.1 in 2002 and 6.8 in $2006^{27}$. In the 2000 s, they created up to $75 \%$ of the new jobs in Kenya and contributed to $18.4 \%$ of the GDP $^{28}$, half of Nairobi's working population being employed in the informal sector, and 20 to $25 \%$ being street vendors ${ }^{29}$. This fact was acknowledged during the colonial era but it became a central developmental stance in the 1970s, in line with the recognition of informal activities by international donors. The Metropolitan Growth Strategy earmarked plots for the creation of 55 markets in the peripheries in order to protect the core of the national capital. They were never constructed due to land-grabbing ${ }^{30}$ and, in the 1980 s, despite official 
support by President Arap Moi, forced removals continued to be conducted by both the central and the local states ${ }^{31}$, according to short-term manoeuvres and ever-changing political agendas, consistent with opportunistic electoral stakes.

As decentralisation and democratisation progressed in the 1990s, public tolerance toward street trading grew. In 1992, a division of informal trading was created within the Ministry of Planning and National Development ${ }^{32}$ and the newly elected City Council (1993) proved temporarily more lenient. But the gap between discourses and practices persisted: in 1997, it teamed up with the provincial administration in order to implement a presidential directive that required the CBD to be cleared of street traders. They were scripted as political opponents who had taken part in political riots and demonstrations ${ }^{33}$. In 2003, following the election of President Kibaki, the Economic Recovery Strategy Paper engaged in a historic shift ${ }^{34}$ : to reintegrate formal and informal sectors in a single policy, an acknowledgement of their symbiotic relationship. Informal trading was said to be "the practical poverty eradication formula" and Nairobi was seen as an incubator of this policy ${ }^{35}$. The National Rainbow Coalition government depended on the informal sector to meet its electoral promises to create 500,000 jobs per year. The 2003 Nairobi Action Plan supported by Mayor Joe Aketch promised to "reorganize hawking by allocating hawkers well-managed spaces within the CBD". But evictions continued, and the vendors were required to go and operate in River Road, the popular section of the city centre. In the run-up to the December 2007 General Election, they were allowed back onto the street of the CBD and scripted as national entrepreneurs in an attempt by the Party of National Unity to win their votes. But after the elections, they were relocated to the Muthurwa municipal market, a $2 \mathrm{~km}^{2}$ area (including the station) that is located next to the major Machakos bus terminal, on a piece of land that belongs to the Kenyan Railways. They were allocated $1 \mathrm{mx} 1 \mathrm{~m}$ stalls that they rent for Kshs50 per day.

[Figure 1a \& Figure 1b]

\section{Shifting imaginaries or the continuation of the colonial spatial reordering?}

The Reconquista of the central space could be seen as the continuation and the eventual realisation of the colonial agenda. Two lines of arguments converge to promote this view:

Firstly, on the discursive level, street trade is still described in neo-hygienist metaphorical terms as a "disease, a malaise" (F. Fadamula, former CEO of the $\mathrm{NCBDA}^{36}$ ) blamed for exacerbating urban decay:

\footnotetext{
"The common practice of display for the trader is to lay a mat or piece of cloth anywhere on the street and put the wares on top and then call for buyers. This makes the trade look ad hoc and an eyesore. ... [our goal is] to make the trade be part of an orderly and civil environment"

(NCBDA, Street Vending in Nairobi and other urban centres in Kenya, 2005, 18).
}

It is referred to as hawking, a derogatory term linked to ideas of vagrancy and loitering that was used by colonial authorities and in the municipal City of Nairobi 'hawkers' amendment bylaws of 2007. The fact that nostalgic public discourses frame the 1950s as a period of splendour that needs to be revived contributes to this idea: colonial mottos are being reactivated by the NCBDA and the NCC, both of which seek to restore the "lost glory of Nairobi" "37, the "glory of yester years" 38 , and the fantasy of "green city in the sun" 39 . 
Moreover, the conception of 'them' (street traders), versus 'us' (legitimate institutions that run the City and shopkeepers/taxpayers) reflects old tensions. Since the colonial era, shopkeepers have tended to see street traders as unfair competitors who sell similar goods at cheaper prices because they do not pay rates and taxes, as exemplified by a letter of the East African Traders Association's general secretary to the Town Clerk in April 1942:

\footnotetext{
"Our objection is based on the fact that (...) [amendments to the 1937 bylaw] will cause conditions which will be entirely detrimental to the shop-keepers operating in the commercial area [the CBD], and by virtue of the fact that they pay enormous amounts of money in licenses and rates are entitled to the protection that has been given them in the past".
}

This conception is still promoted by public action. In 1997 for example, restrictions on street trading were implemented in order to justify an increase in the taxes enforced on the formal trading sector ${ }^{40}$. Moreover it plays on inherited tensions between Africans and Indians ${ }^{41}$, and on the political construction of street trade as an African object, as opposed to the tradition of the Indian market, historically embodied by the Biashara Street Bazaars: "our members are a sore subject and sight in their beauty spots in the city", referring to "well-to-do shop owners, Asian grocers" 42 . It overshadows the process of "indigenisation" of trade (Yahya has shown that Indian shopkeepers in the city centre started to sell their shops to African entrepreneurs in the $1980 \mathrm{~s}^{43}$ ), as well as the encounter of the tradition of trade of the Indian community of Nairobi with Muslim African economic elites from the coast (the watajiri - the "rich") at the beginning of the $\mathrm{XX}^{\text {th }}$ century ${ }^{44}$.

Secondly, in terms of planning tools, the City of Nairobi bylaws that were passed in 2007 reactivated "dormant bylaws" 45 on street trading: they made cosmetic updates to the colonial document of 1963 that had fallen into disuse. Under these bylaws, street traders are compelled to design a clear outline for their stalls and to display individual registration numbers, a measure that was contested by the Kenya Auctioneers, Hawkers, Marketers and Traders Union in the 1960s. Moreover, after decades of disruption due to its inability to enforce it, in the 2000 s, the NCC reintroduced the compulsory licensing. This led to the creation of a centralised database. Anthropometric photographing was abandoned, but censuses were undertaken, a measure that was seen as a way to discern the "authorised" traders from the "outlaws". Old dividing lines were reactivated through this process: In an opposition also found during the colonial era ${ }^{46}$, shoe-shiners and newspaper vendors were said to provide a valuable service to the upper classes ${ }^{47}$. They were supported by corporate firms (e.g. KIWI, a shoe polish and shoe brand uses their stalls to advertise its products), whereas "general sellers" ${ }^{48}$, who sell meat, cooked food (like uji- porridge), fruits, vegetables, cheap clothes and electronics, and who display their merchandise on the pavement were deemed undesirable in the CBD.

Nevertheless, today's debates are also being reshaped along new urban imaginaries: what should an African urban identity be in a globalizing world? Should the city centre be designed for international tourism, corporate interests and expatriates, at the risk of losing its African identity, also an asset for tourism? How to deal with the presence of African vendors who do not only sell curios and handicrafts next to luxury hotels and administrative buildings? The challenge is to reconcile the dreamed skyline of the modern capital, a once successful independent African capitalist metropolis, as it is captured in the outline of the world famous Kenya International Convention Centre, with a modern African identity. What is at stake is the 
shop-window strategy, the image of the vibrant commercial city centre conflicting with the neatness that corporate firms seek to promote. Quite tellingly, the first motto of the NCBDA was: "Nairobi the choice of Africa, clean, secure, and vibrant".

Within this context, street trading can be conceptualised as "the antithesis of neo-liberal models of development and modernisation" 49 embodied by the futurist vision encapsulated in the Nairobi Metro 2030 vision (Figure 1b). This document of long-term strategic planning draws from the role model of Mumbai. It depicts Nairobi as a hyper modern and connected "World Class African Metropolis"50. It echoes the national Vision 2030 First Medium Term Plan 2008-2012 that seeks to promote a "Globally Competitive and Prosperous Kenya". Both documents were funded by the World Bank. They reflect the entrepreneurial yearning to make Kenya, framed as the last emerging market, compete with the Asian Tigers by $2015^{51}$. Nairobi's metropolitan economy does indeed represent $50 \%$ of the $\mathrm{GDP}^{52}$, and the competitive capacity of its CBD is considered a strategic lever for economic growth. Local Economic Development (LED) is a major injunction from international donors and a component of the national Poverty Reduction Strategic Paper ${ }^{53}$. As a result, the National Development Plan $^{54}$ recommends better control of Nairobi's CBD and the Metro Vision recommends relocating street traders to peripheral markets.

\section{Street trade under the rule of neoliberal governance}

\section{Neoliberal governance in the making: the difficult crafting of an effective PPP}

In the 2000s, corporate firms invited themselves into this debate, arguing that they could come up with innovative solutions to a "perennial problem" unable to address. Repeated attempts to relocate the traders to the suburbs had failed in the past (Figure 2). They kept coming back to the CBD, reasoning that trading was too slow in the peripheries. The NCBDA started to target street trading, together with other urban blights that were said to impede economic growth by discouraging foreign investment and tourism. Regular accounts in the newspapers of violent clashes between the Police and street traders, a wellknown feature of Nairobi in pre-election time, were said to tarnish the image of the city, thus the urgent need for the private sector "to seek a solution to the problem of hawkers" 56 and to "lock them out of the city centre" 57 . It constituted a major break from the state-driven process that had hitherto taken place.

The Nairobi Central Business District Association

The NCBDA is a non-profit private organisation. It was founded in 1997 by Sandy Vohra, the managing Director of Savora hotels (a company that has two hotels in the CBD and whose parent company is based in the UK) with nine other businessmen. Primarily anchored in the Indian Business community, the NCBDA has grown to 100 corporate members, mainly from the FIRE sector (40\%), manufacturing industries (17\%), and the hospitality industry (15\%) (e.g. Hilton Hotel, Old Mutual, Total Kenya, British American Tobacco, Telkom Kenya ...). Its annual budget amounts to KShs 2 to 3 million $(17,000 €)$ but it represents a financial base of Kshs150 billion ( 1.25 billion $€$ ) and it "contributes well over $20 \%$ of the GDP" 58 . The 
NCBDA defines itself as an "advisory group [that] represents business interests", as an "agent of change" (interview with a NCBDA project manager) that seeks to transform Kenya "into a vibrant, stable and investor friendly destination in the region"59. It focuses on the revitalisation of the CBD. True to its entrepreneurial ethos, it supports public-private partnerships and the privatisation of services. Several members of its governing council belong to the Athi Water Board that was set up when water management was privatised in Nairobi. The NCBDA's activities range from the management of street trading to community policing, refuse removal, street lighting, the upgrading of public toilets, the greening of the streets, etc. Its programmes are funded by private donors, mainly the Ford Foundation, CORDAID, USAID, and the UNDP.

Corporate interests' activity found a favourable ground in the rescaling of public action at that time. The Local Government Reform Programme ${ }^{60}$ accelerated the process of political decentralisation. However, although the Local Authority Transfer Fund System of 1998 stipulated that the central government had to allocate $5 \%$ of the national income tax to local authorities, the NCC was chronically under-resourced, a situation that has hardly changed since its creation in 1919. The "starving" $\mathrm{NCC}^{61}$ became proactive in terms of LED with the entrepreneurial turn, and increasingly eager to protect the value of the properties of the CBD for the taxes it levies on land and buildings account for $60 \%$ of its revenues ${ }^{62}$.

This argument was astutely put forward by corporate firms: "The effect of their [street traders] influx on property values is ... significant as corporate tenants have had to vacate key properties within the CBD" ${ }^{\text {" }}$. Consulting firms, insurance companies and donor agencies such as the World Bank and the British Department for International Development had indeed moved to the suburbs in the 1990s, a trend that was blamed on image issues and that the NCBDA wished to reverse: "Street vending can also have very negative effects as seen from the influx of street vendors between year 2000 and 2002 leading to ... a higher sense of insecurity that saw some companies and organizations exit the Central Business District",64.

However, despite an obvious convergence in goals, the building of the PPP proved a complex exercise. The NCBDA was initially considered by the NCC as "an activist group". It defined itself as a "watchdog" created to "lobb[y] the Government for better services vis a vis taxes paid" 65 and "keep them on their toes" (interview with project manager). The tensions between the NCBDA and the government were high regarding the issue of street trade. The NCC's attempts to relocate the traders to Ngara, in 2004 (Figure 2), were scripted by the NCBDA chairman as "an arbitrary approach" to "wash away the lives of over 8,000 traders". From an aggressive tone towards the "greed and personality cults in the local governments" however, the NCBDA progressively turned to a partnership approach. Its representatives started to talk of "partners", of "a mutual relationship", of the need to "work hand in hand", of "mutual trust" in the name of a shared interest, i.e. "to turn around the face of Nairobi" ${ }^{67}$. Kamunyori suggested that the change at the head of the NCBDA (2000) contributed to this shift ${ }^{68}$.

Today, the NCBDA does partner with the Nairobi City Council, the Kenyan police services and the provincial administration: they sit on its governing council. But as there is no legal 
framework for PPP in Kenya, the principles embodied by consultative forums of cooperation such as the Nairobi City Council Stakeholders' Forum set up in 2003 in partnership with KEPSA (the Kenya Private Sector Alliance) progress slowly. The fact that the Memorandum of Understanding that had been signed between the NCC and the NCBDA in 2001 was never renewed for reasons that were carefully omitted by interviewees and despite the fact that a former NCBDA chairman was appointed Town Clerk in $2009^{69}$, exposes the tensions between private and public stakeholders and the difficulty of building an effective PPP.

\section{Redrawing a "cartography of exception"}

Wherever local governments strive to regenerate their city centres in order to achieve world-class status, street trading ends up lying at the heart of a scalar tension: it is judged valuable in terms of poverty alleviation at the national and metropolitan levels, but it is deemed undesirable in the urban cores that are targeted as strategic economic territories. The agendas of the NCBDA and of public authorities thus met on a territorial consensus: The creation of the Muthurwa market formed part of a spatial containment scheme whereby all traders would have to operate from designated and earmarked areas outside of the CBD. The crafting of placebased policies that contributed to drawing "a cartography of exception"70 regarding the uses of the CBD was aimed at reconciling these two developmental concerns. Overcrowding, the shortage of market space, and the lack of infrastructures in the CBD were mentioned to justify the displacement ${ }^{71}$. Similar efforts to force matatu companies to operate from peripheral nodes (bus terminals and large roundabouts) reflected corresponding attempts to protect the central space while complying with economic constraints - the matatus bring an estimated two million commuters to the CBD daily.

The NCC promised to redevelop the City market and identified "appropriate hawking zones" and "vacant plots" in the peripheries in order to build 19 formal retail markets, one wholesale market, five self-constructed markets and seven tenant-purchase markets ${ }^{72}$. It communicated firmly on this policy:

\footnotetext{
"The city council of Nairobi wishes to warn the public that unlicensed hawking or buying from hawkers, negotiating, inducing or bargaining hawked goods in the non-designated areas is an offence contrary to the City Of Nairobi hawker's By-laws 2007 and will not be condoned forthwith" (F.O. Mwanza, Chief PR officer, 28/02/2008, www.citycouncilofnairobi.go.ke, accessed February 2009).
}

This policy seem to be nothing new: the Ministry of Local Government had created markets and promised to upgrade existing ones since the 1960s; the Local Government Act (CAP26, 1977, section 145) stated that local authorities should "prohibit ... sales elsewhere than in or at such market". However, it mentioned the need to provide formal trading facilities within the CBD, and until the 1990s, discussions had taken place with the UNDP regarding the building of kiosks in the city centre. Street trading in the CBD was strictly prohibited only after the passing of the 2007 municipal bylaws. This measure did not exist in the 1963 document. For this purpose, the bylaws were toughened: clients who purchase a good from an unlicensed trader may be prosecuted; the vendor may be jailed for up to six months and have his/her goods seized (they will be returned to him/her in exchange for a fine). In the colonial bylaws, the confiscation of their goods was not possible, a problem stressed by the Town Clerk in his 
correspondence with the African Court regarding a court case involving the illegal confiscations of goods from "unauthorized hawkers", in May 1960.

The MoU signed between the NCBDA and the NCC in 2001 stated that the NCBDA mandate covered "the inner core of the CBD" as well as "the CBD and its environs"73. This expression was used during the colonial era to designate the city core and its extensions (River Road to the east and upper hill, an administrative suburb to the west). But the NCBDA concentrates its activities on a shrinking urban core, the spaces of international capital where it has reclaimed small and emblematic portions of the public space: the Kenyatta Avenue, the surroundings of the New Stanley Hotel where the Standard Chartered Bank, the Stanley Hotel and Pan Africa Insurance are supporting a micro Business Improvement District, and portions of central streets that have been pedestrianized, e.g. Mama Ngina Street, opposite the city Hall and close to the Hilton hotel. The River Road area, a thriving commercial area where most African businesses are found, but a "no-go zone" for tourists and for the business elite, has been set aside (Figures 2 and 3).

Muthurwa thus appeared as a spatial compromise: "telling Nairobi vendors to move to the far end of the city, they would not accept (...) [in Muthurwa] they can move out of the town but not be too far from the customers" (Interview with KENASVIT representative). The city centre is indeed the lower cost / higher return location: goods can sell for a higher price there, which covers the transport costs (the majority of street traders live 10 miles away from the $\mathrm{CBD}$, in Githura and Kayole ${ }^{74}$ ) and it is easier to reach a large clientele of commuters with a good buying power:

"In the CBD, I need 1 to 2 hours but in Muthurwa I can spend even all day without earning anything ... habit shows [that there is] a much bigger flow of people in the CBD ... you can get a customer easily, not like in Muthurwa ... you can sit here all day long and sell not one thing" (interview with Beth, trader).

As stated by an interviewee: "It's not really very fair but it is a bit fair", implying that being relocated next to a major bus terminal and close to the CBD was not such a bad deal.

As a result, three groups of traders (at least) emerged from this spatial arrangement, as evidenced in the traders' discourses: those who are "busy" but "piled up" in the "upper section" of the market (closer to the CBD) and for whom "Muthurwa is in the CBD"; "the back ones who have no customers end up with no money from that space", i.e. the "lower section" of the market that is said to be "half-empty"; those of the lower section who went back to sell in town because business was too slow. In the last section, I turn to an analysis of the participative process that pushed all the traders to accept a spatial compromise that was detrimental to them.

[Figure 2]

[Figure 3]

\section{"We were not forced but compelled to go there": participation and the government of mentalities}

In the 2000s, democratisation had opened the door for consultative processes, a positive move towards the recognition of street traders as fully-fledged partners in discussion. They 
were invited to participate in Government-led discussions on the National Land Policy Development and on the SME Bill ${ }^{75}$. At the same time, the NCBDA approached them with the purpose of convincing them to renounce confrontational practises and accept the relocation to Muthurwa. The consultative process was conceived as "a strategy of making them [street traders] share the goal and vision of other stakeholders in the City"76. It straightjacketed discussion into consensual debates aimed at forestalling political protest ${ }^{77}$. As stated by a NISCOF trader: "We were not forced but compelled to go there". This goal was achieved through (i) the reframing of the political significance of street trade along entrepreneurial lines, (ii) a process of institution building, and (iii) the valuing of responsibility and collaboration (as opposed to political protest) as attributes of respectable citizenship.

\section{"Hawkers, you can partner with them or become enemies": reframing the significance of street trade along entrepreneurial lines}

In 2001, the NCBDA organised a survey of street traders and two consultative workshops with their associations, using USAID funding ${ }^{78}$. As a former NCBDA official stated straightforwardly: "we wanted to determine whether hawkers actually had an economic value"79. The survey revealed that the "value of the stock" of informal trading amounted to Kshs70 million daily (around 600,000 $)^{80}$. Whatever the reality, it made a great impression on NCBDA members. Henceforth, this figure was repeated in the NCBDA material in an incantatory manner ${ }^{81}$. The NCBDA claimed that it wanted to "partner" with traders ("hawkers, you can partner with them or become enemies" - interview with the chairman), by "includ[ing] them" in its governing council "together with professionals", and that it represented all the components of the private sector ${ }^{82}$. It recognised that street trading had a "role in City growth" $" 83$, and that past attempts to curb it had constituted counterproductive efforts that had led to "mistrust" and tarnished its image among street traders ${ }^{84}$.

"[The NCBDA] is no longer an elitist organization for big Corporate Organizations as was earlier perceived, but an all-inclusive body of change" (NCBDA CEO, www.ncbda-kenya.org, May 2008, accessed February 2009); "It ... took the informal trader's time to develop a working level of trust in NCBDA which it originally viewed as an association of formal traders" (USAID, quoted in NCBDA 2004d).

The vocabulary changed. Street traders were referred to as jua kali artisans, as "entrepreneurs" 85 , and as a "segment of the business community" that "need[ed] a better organisation" (P. Kisia 2001, former chairman of the NCBDA).

While praising consultation however, the NCC continued to insinuate that street trading created the conditions for criminality (crowding, contacts in public space...): "uncoordinated hawking is creeping back to the streets of the CBD" $" 86$. The NCC propensity to hold onto a strong-arm tactic ${ }^{87}$ may be linked to a sense of loss of control: although the Local Government Act has delegated the control of trade to local authorities (section 163), street trade remains under the combined pressure of the local and national governments. It is due to political tensions that partly echo ethnic and regional affiliations, slowing down decentralisation. The City is thus sometimes bypassed by the State: for example, City officers were refused access to the market during the construction of Muthurwa because it had become a major political stake in a preelection time, leading to a political competition for the appropriation of this 'success story'. 
Despite these difficulties, the NCBDA succeeded in bringing together the state and the traders, by pointing out that it was in their interest to cooperate as entrepreneurs: the City was offered the guarantee that it would be able to enforce rules and regulations aimed at fostering urban entrepreneurialism, and for the first time, street traders were not discursively constructed as undesirable others but treated as partners, as "stakeholder" (a word re-appropriated by the traders), and invited to forge an alliance with capitalist elites. Prestigious academic institutions played a key role in this process: in 2002, the Institute for Development Studies of the University of Nairobi was pivotal in the creation of KENASVIT, an umbrella organisation that supported the consultation process ${ }^{88}$.

\section{“We want you to be one people": Institution building and the co-optation of protesters}

Street traders were warned that they had "to show unity of purpose and solidarity if they [were] to be taken seriously by the authorities" $" 89$. They would be granted a "consultative status provided they formed a single consultative body" 90 . "Informal traders should be assisted to become more organised preferably under one umbrella organization as this will enable them to participate in policy development" negotiate with organized and registered bodies" "92; the Deputy Provincial Commissioner welcomed "a program that [sought] to organise informal traders into governable bodies; the Director of City Inspectorates stated that "an informal traders association would give the City Council an entry point into planning for informal traders" $" 93$. The matatu operators were invoked as role-models.

NISCOF, the Nairobi Informal Sector Consultative Forum -soon renamed the Nairobi Informal Sector Confederation, was thus formed in 2004. It federated 23 associations. NISCOF has a spatial focus, as opposed to associations or trade unions that serve corporate interests. It has evolved from NCBDA-related activities. Its members envision the NCBDA as a sympathetic mediator that "saw what the City Council askaris do to us". From 2005 to 2008, NISCOF was incubated by the Corporate Renewal Centre (CRC, a small local enterprise). It paid for the rent of NISCOF and gave its representatives access to its office and computers. CORDAID funded the team building and training needs. Prominent businessmen sit on NISCOF's board, e.g. the managing Director of Swizz Connect, the managing Director of Corporate Insurance (an expert at the SME sector), the Exco of CRC, and the NCBDA chairman was elected chairman of NISCOF in 2007.

This process of institution building has positioned NISCOF as the sole legitimate partner for public authorities, despite attempts by other groups to form competing structures (other groups, such as the Wananchi Hawkers and Traders Association, broke with NISCOF). It enjoys the reputation of being the only democratic organisation of street traders in Nairobi: it organises internal elections every three years and its staff has received training from the NCBDA. It has gained international recognition (it is hosted on the StreetNet website, a transnational organisation that networks street traders' associations worldwide). As a result, and although NISCOF represents only between $15 \%$ and $23 \%$ of the 65,000 to 100,000 vendors of Nairobi, it monopolises the platforms of dialogue with the government: the NCC Stakeholders' Forum (2006) that instigated the reviewing of the bylaws; the NCC Partnership Board, a space of 
dialogue between street traders, the formal sector and the local government; the Stakeholders' Forums on Taxation and Accountability ... It is also a member of the influential Kenya Private Sector Alliance.

The creation of NISCOF reflected a legitimate effort to overcome the lack of leadership among street traders and to avoid commonplace abuses by ill-intentioned 'briefcase leaders' (people who take advantage of their position, sometimes running away with the associations' money). It was also presented as a means to channel the energy of the identified $58.7 \%$ vendors who belonged to no formal registered association ${ }^{94}$ and of the $24.6 \%$ who belonged to unregistered associations ${ }^{95}$. However, against historical evidence, the NCBDA narrative overshadowed the organisational capacity of street traders: they had engaged in a dialogue with public authorities and got organised to lobby for their rights well before the NCBDA was created. In 1993, they had raised a voice at the "Nairobi we want" convention public hearings to denounce the infringements on their rights; numerous locally-based associations and national groups had formed after the democratic turn of 2002 that had engaged in a dialogue with local authorities in Mombasa, Eldoret, Migori, Machakos, Kisumu, Nakuru and Nairobi. Even during the colonial period, street traders interacted with the colonial administration through associations of licensed vendors and trade unions. They opposed municipal bylaws and went to courts. For example, on June 23, 1962, the Kenya Auctioneers, Hawkers, Marketers and Traders Union and the Nairobi Vegetable and Fruit Hawkers and Traders Association complained about the "oppressive parts" of the municipal bylaws, asked for amendments and denounced the violence of the Police. Their complaints were examined by a subcommittee for street trading within the City Council and they obtained a meeting with the City of Nairobi.

\section{“As hawkers you have a bad reputation": citizenship, respectability, and responsibility}

The NCBDA painted the relocation to Muthurwa as the consensual outcome of a smooth process: "The relocation revealed the willingness of the traders to work with the Council and other stakeholders" $"$. NISCOF members painted a different picture of the "Muthurwa saga". They recalled that they got a market only after having demonstrated against a municipal attempt to relocate them to "new Ngara", in application of the 2007 bylaws that prohibited street trading in the CBD. The demonstrations degenerated into violent clashes, and several people were killed. They said that they came up with the idea of Muthurwa, as a "viable site". They complained that "acute chaos" erupted over space allocation because they were not involved in the planning process. A first come, first served policy was used to hasten the relocation (not to mention protection racket, clientelism and stories of occupation of the market at night by competing groups): "the allocation was very chaotic"; "it was not in order"; "there was no prior arrangement by the NCBDA"; "it was out of their control"; people "ended up fighting for space"; "people were so wild, they broke the gate" and women were mauled by young men who pushed past them.

Conflicting narratives of this episode were expressed through which the NCBDA pushed forward a discourse on consensus decision-making in order to discredit political contestation, deemed dangerous and violent: 
"The most outstanding achievement of NCBDA is enhancing 'inclusion' through the many relationships built. Groups and individuals from all kinds and diverse circumstances have been united to work towards their common and heartfelt goals for Nairobi" (NCBDA's chairman, www.ncbda-kenya.org, May 2008, Accessed February 2009).

"What works is ... starting from a passive, non-confrontational mode when dialoguing with the local authorities; abiding by existing by-laws while at the same time advocating for their revisions and amendments" (consultative workshop, NCBDA 2003).

At some point, this discourse met the street traders' search for respectability. As underclass citizens, they suffered from a lack of credibility, a weakness that was instrumentalised by the NCBDA chairman: "I warned them: as traders, you have a bad reputation" be recognised as a legitimate partner was a powerful one. Street traders thus largely tended to frame their demands along entrepreneurial lines during the consultation process, as opposed to human rights claims, discourse framed around the right of the poor or a demand for the redistribution of wealth. They claimed that they provided the underpaid with cheap service and goods in the CBD and that they enabled many poor persons to earn a living: "the government is not creating jobs. The only sector that is creating jobs is the informal economy"98:

"We want to be treated with respect like other Kenyans in the formal sector because we also contribute to growth of the economy" (Charles Kalomba general secretary of the Kenya National Federation of Hawkers, quoted by the Standard, 15 July 2009).

Paying taxes gave them a bargaining tool to demand services and political dignity: their licenses contribute to over KShs50 million to the municipal budget yearly ${ }^{99}$, i.e. one third of the NCC revenue and its third source of income. This was remaindered by NISCOF at the national Stakeholders' Forum on Taxation and Accountability in 2006. This was also acknowledged within government circles:

"It is estimated that hawking moves goods worth KSh1 billion annually, most of them untaxed; the launch of [KENASVIT] is geared toward ensuring that ... the government can get its share of revenue from the hawkers activities" (Kenyan Times, 25 April 2006, quoting the Permanent secretary in the ministry of Local Government).

NISCOF members also described themselves as "agents of change", as opposed to conservative forces, those who are "addicted to the street", a normative labelling with a moral, if not medical connotation: "We have some members who still work in the CBD. We don't condemn them. We try to show them ... the difference, slow by slow, a small kiosk you know, but some of them...".

They stressed the importance of spatial assignments in the building of a political legitimacy based on entrepreneurialism (the trader versus the hawker): "When we are in the streets we are hawkers. When we are in the market, we are traders".

Moreover, they naturalised the entrepreneurial image of the market, framing it as a place where one can secure an entrepreneurial success story:

"You can't have a future in town"; "in the street you cannot plan your business ... sustain your business"; "if you make a customer you'll see that customer will be available tomorrow ... it is a matter of time"; "we want to make sure that our vendors will not be in the street for their life."

Intriguingly, the traders I interviewed used the same word, "freedom", to describe their experience in the streets of the CBD and in Muthurwa. Two conceptions of freedom of 
enterprise are encapsulated here: peace of mind, dignity and frugality in Muthurwa, found only in a market ("there is no other place where there is freedom") vs. unsteadiness and uncertainty but affluence in the CBD. At the same time, as they recognized that Muthurwa is a "space not much conducive for business".

These responses give us a glimpse of the shift occurring in the rationalities around entrepreneurial criteria of legitimacy: individual responsibility, being a taxpaying citizen, business freedom, adaptability and economic opportunism... However, these criteria combine with other registers, notably moral or political, unconnected with neoliberal principles. A detailed examination of these combinations remains to be done. For example, entrepreneurial discourses combined with fatalistic stances tainted with Christian values that helped make the traders accept the hardship: "Just accept, just remain patient"; things will not improve "unless God comes"; "we must negotiate with the government because we are their children". Moreover off the record, some traders condemned the lack of dialogue with the City regarding the updating of this bylaw. The process was described as "secretive"; they could not access the drafts: "it's like you pull out a part of the Bible". They debunked the lack of participation regarding the drafting of this document, articulating a political (and not entrepreneurial) conception of citizenship: "don't put a law on me like I am not a citizen" 100 . They mentioned their attempts to bypass the City and reach for the national government (that they saw as more sympathetic) in order to go back to the city centre, still a largely shared and cherished goal; they mentioned discussions around 'model kiosks', and their efforts to "convince the government to let [them] work 24 hours in the CBD"... They obtained a rebate of $50 \%$ on the daily fee after having petitioned and protested. As a result, to assess their capacity to contest this spatial order and their resistance to the entrepreneurial stance, we need to investigate their agencies further, drawing from Lindell's work in other African contexts (2010), notably their ability to resort to international alliances such as the Women In Employment Globalizing.

\section{Conclusion}

After decades of fighting to access the CBD, Nairobi's street traders seem to have given up on the right to work there, at least for the moment. This outcome was achieved through a consultative process unprecedented in the history of Nairobi. It was let by a powerful association working on behalf of the big private companies, whose consultative practices represent a break with a national and local culture of violence and repression. This process led to a spatial consensus based on the promise of a maximization of individual well-being for the traders and more peaceful relations with the authorities. The methods of regulating street trading in central Nairobi thus seem to be evolving alongside the emergence of a shared entrepreneurial emphasis and mixed governance. The suspension of a cycle of violence that has caused many traumas since the colonial period comes at the price of the spatial confinement of a now overpopulated market: Muthurwa was planned to accommodate 8000 stalls; more than 12,000 stalls were counted in 2013, and hundreds of people were obliged to set up stall around the market.

However, local government continues to rely on repressive practices and the exercise of its sovereignty: in 2007, it updated and toughened the municipal order that has regulated street trading since colonization, which could signal the emergence of new power arrangements, in 
which, rather than replacing violence and direct forms of exercise of power, neoliberal governmentality is superimposed on them to form unpredictable, arbitrary and fragile combinations. In addition, the very localized Muthurwa episode should not be taken as evidence of the general emergence of new liberal modes of government at citywide scale or in all areas of urban life. State violence remains dominant in Nairobi and indirect government (embodied here by the introduction of participatory methods) would seem to play only a secondary role to discipline, in particular when the latter breaks down. So while the theoretical framework of neoliberalization may bring factors that qualify our understanding of the modes of regulation of street trading in conditions of democratization, and open up avenues for the exploration of the forms of exercise of power in contemporary Nairobi, its relevance in a postcolonial context and its connection with colonial/postcolonial dynamics require further investigation.

\section{Acknowledgements}

This work was supported by the French National Agency for Research (ANR) under the Jugurta programme, directed by Philippe Gervais-Lambony. I express my appreciation to IFRA-Nairobi and to its former Director Bernard Calas, who welcomed me during my field work. I am very grateful to Hélène Charton and Sam Owuor who invited me to the launching of their CORUS research programme ("Governance, informality and identity in Nairobi and Dar as Salaam"). I thank Winnie Mitullah and Sam Owuor from the University of Nairobi (who also participated in the Jugurta programme), Lydia Muthuma, Anne Bousquet and Quentin Mercurol who helped me to find my intellectual way around Nairobi. This paper owes a lot to the discussions I had with Sophie Didier and to our work on Cape Town. I also thank Claire Bénit-Gbaffou and Marie Huchzermeyer for their comments and suggestions, and Jean-Fabien Steck for sharing with me his knowledge on issues of informality in African cities. The opinions expressed in this paper are entirely mine.

\section{Notes}

1. Hart, Entrepreneurs and migrants.

2. I use the descriptive and neutral term street trade, rather than the expression jua kali, which has historical connotations linking it to a process of political recognition, or the term hawking, which is still heard in Kenyan political discourse but which has a pejorative and colonial connotation. Street trading designates any form of trade that takes place in public space, whether legal or illegal, sedentary or mobile, provided it is targeted by the neoliberal spatial reordering.

3. Lewinson, "Reading modernity in urban space".

4. Yankson, "Accommodating informal economic units in the urban built environment".

5. Popke and Ballard, "dislocating modernity"; Skinner, "Falling through the policy gap".

6. Steck et al., "Informality, public space and urban governance".

7. Kenya National Bureau of Statistics, Population and Housing census, 2009.

8. City Council of Nairobi, 2006, Strategic plan 2006-2010.

9. Rajagopal, "The violence of commodity aesthetics"; Simone, For the city yet to come; Slaughter, "Master plans"; Linehan, "Re-ordering the urban archipelago"; and Fourchard "Les rues de Lagos".

10. Brenner and Theodore, "Cities and the Geographies of "Actually Existing Neoliberalism" ".

11 Nadesan, Governmentality, 6.

12 Nadesan, op cit., 15

13 Nadesan, 15

14. For such an approach, see Macharia, Social and Political Dynamics; Mitullah, Street Vending in African

Cities; Lyons, "Creating Urban Social Capital"; on the transnational networks of informal trading, see Campbell, "Economic globalization from below" or Gadzala, "Economic globalization from below".

15. Files 0108632 RN/1/106; 010957 RN/8/4; 0119772 RN/1/1; 0119776 RN/1/5 By-law hawkers 1937-1963, stored in the National Archives in Nairobi.

16. In the quotations, the emphasis is mine.

17. Macharia, "Tensions created by the formal and informal use of urban space".

18. NCBDA, Street Vending in Nairobi, 2005, 21.

19. Ibid.

20. NCBDA, Appropriate governance system for informal trading program, 2004, 6 (NCC data).

21. Ibid. 
22. Thornton-White, Nairobi Master Plan.

23. Médard, "Nairobi : acteurs et enjeux d'une planification détournée".

24. On the criminalisation of poverty and of the poor, see Burton, African underclass, and Rizzo, " 'Life is War'!" (on urban transports in Tanzania).

25. Republic of Kenya, Sessional Paper $N^{\circ} 1$ of 1986 on Economic Management for Renewed Growth, Nairobi: Government Printer, 1986.

26. Republic of Kenya, Sessional paper $n^{\circ} 2$ of 2005 on Development of micro and small enterprises MSEs for wealth and employment creation for poverty reduction, 2005; Central Bureau of Statistics, Report of the 1998/99 Labour Force Survey, 2003.

27. Linehan, op. cit. 29.

28. NCBDA, op. cit.

29. Kamunyori , "A growing space for dialogue", 9.

30. Klopp, "Pilfering the public".

31. Due to the tradition of centralisation, the NCC falls under the control of the Ministry of Local Government that appoints the Town Clerk.

32. Republic of Kenya, Sessional Paper $N^{\circ} 2$ of 1992 on Small Enterprises and Jau Kali Development, Nairobi: Ministry of Planning and National Development, 1992.

33. Médard, op. cit.

34. Republic of Kenya, Economic Recovery Strategy for Wealth and Employment Creation (2003-07), Nairobi: Ministry for Planning and National Development, 2003.

35. NCBDA, Survey Report on Street Vending in Nairobi, 2004.

36. NCBDA, Citypower, January 2005, 2.

37. NCBDA, Organized hawking in the CBD.

38. NCBDA, Citypower, January 2005, 1.

39. See the municipal pamphlets: Nairobi City in the Sun of 1962 and A guide to Nairobi city in the sun of the 1950 s.

40. Médard, op. cit.

41. Prunier, "Les communautés indiennes".

42. African Councillor Serikali, TaifaLeo, 30/12/1961.

43. Yahya, Urban land policy.

44. John Lonsdale, "Etre citadin".

45. Town Clerk, quoted by the Kenyan Times, 1 May 2006.

46. Elkan et al., "The Economics of Shoe Shining".

47. NCBDA, Shoe Shining Stands in Aga Khan Walk Project, 2005.

48. NCBDA, Organized hawking in the CBD.

49. Linehan, op. cit., 21.

50. Republic of Kenya, Nairobi Metro 2030 strategy. A World Class African Metropolis, Building a safe, secure and prosperous metropolitan, Ministry of Nairobi Metropolitan Development, 2008.

51. Republic of Kenya, Vision 2030. A Globally Competitive and Prosperous Kenya 2008-2012. Nairobi:

Ministry of State for Planning, National Development and Vision 2030, KIPPRA, 2008.

52. Kamunyori, op. cit., 64.

53. Republic of Kenya, Poverty reduction strategic paper 2000-2003, Nairobi: Government Printer, 2000.

54. Republic of Kenya, National Development Plan 2002-2008, Nairobi: Government Printer, 2002, 46.

55. NCBDA, New Year Bulletin, 2005, 1.

56. NCBDA, Survey Report on Street Vending in Nairobi, 2004.

57. NCBDA chairman, May 2009, quoted by the Standard.

58. NCBDA chairman, quoted by Okoth, Kenya National Street Vendors Forum.

59. NCBDA, Appropriate governance system for informal trading program, 2004, 26

60. Republic of Kenya, Ministry of Local Government. Strategic Plan 2004-2009, Nairobi: Ministry of Local Government, 2005.

61. City Council of Nairobi, Strategic Plan 2006-2010, 2006.

62. Anyumba, Planning for crime prevention.

63. NCBDA, Street Vending in Nairobi, 2005, 20.

64. NCBDA, Survey Report on Street Vending in Nairobi, 2004, 43.

65. Sandy Vohra, quoted in NCBDA, Citypower, February 2006, 3.

66. NCBDA, Citypower, January 2005, 2.

67. Interview with a NCBDA project manager.

68. Kamunyori, A growing space for dialogue.

69. Several interviewees mentioned embezzlement and corruption scandals linked to NCBDA run public toilets in the CBD. 
70. Linehan, op. cit., 32.

71. NCBDA, Survey Report on Street Vending in Nairobi, 2004.

72. NCBDA, Appropriate governance system for informal trading program, 2004.

73. Hendricks, Urban livelihoods, 153.

74. Kamunyori, op cit.

75. Mitullah, "Struggles and organised responses of informal traders".

76. NCBDA, op. cit.

77. For a similar analysis in post-apartheid Durban and Cape Town, see Ballard, "Between the community hall and the city hall" and Morange, "Participation, neoliberal control and the voice of street traders".

78. NCBDA, Appropriate Governance System for Informal Trading in Nairobi. Proposal to USAID, 2003.

79. Quoted by Macharia, op. cit.

80. NCBDA, Appropriate governance system for informal trading program, 2004, 25

81. NCBDA, Street Vending in Nairobi, 2005, 7

82. NCBDA chairman, interview.

83. NCBDA ibid., 4 and 9.

84. NCBDA, Appropriate governance system for informal trading program, 2004, 41.

85. NCBDA, Street Vending in Nairobi, 2005, 29.

86. Nairobi Mayor, at the launching of the consultative workshop, quoted in NCBDA, Survey Report on Street Vending in Nairobi, 10.

87. See for example, The Daily Nation, "Council destroys more kiosks", 22 May1998, "Hawkers rebuild kiosks", 25 May 1998, "Tension high as hawkers are evicted", 23 May 1999, and the Business Daily Africa, "False solutions to hawker problem will fail", 19 March 2008.

88. Mitullah, "Street Trade in Kenya".

89. NCBDA, Survey Report on Street Vending in Nairobi, 2004, 30.

90. NCBDA, Appropriate governance system for informal trading program, 2004, 19.

91. NCBDA, Survey Report on Street Vending in Nairobi, 2004, 2.

92. Ibid., 9.

93. Ibid., 28.

94. NCBDA, Street Vending in Nairobi and other urban centres in Kenya, 2005, 13.

95. NCBDA, Appropriate governance system for informal trading program, 2004; NCBDA, Survey Report on Street Vending in Nairobi, 2004, 13.

96. Chairman of NCBDA, quoted in NCBDA, Appropriate governance system for informal trading program. 2004.

97. Personal interview.

98. Interview with NISCOF member.

99. NISCOF pamphlet.

100. Interview with Aisha, trader. 